これら以外の要素として考えられることは第一に希薄溶液では 早く拡がる結果, 溶媒の蒸発が早くある程度拡がると溶液はすみ やかに濃厚となり，膜は粘弾性体になり，2次転移点が常温付近 になる濃度に達する。この濃度が重合度によって異なること。第 二に低重合度のほうが可塑性にそしく重なりあった状態で固定化 するが，高重合度のほうは結晶化しにくく分子が横になって水面 上に並びらごきやすいこと。第三に同一試料をアセトンー水で分 別すると高重合度のほ5が幾分硝酸基が多く，低重合度のほうが 幾分水酸基が多いので, 前者のほうが凝集力も水面との付着力も 小さい。第四に蒸発によって拡がりつつある層内に密度の差によ る対流が生じ低重合度分子は水面に縦に向いたまま固定化する, 等の原因が考えられるが，これらは今後の実験結果にまちたい。
塑剂が入ると同一温度でも払がりは相対的に大さくなり，A点は 高温側の B点に移動する。ここでも粘度の影響は大きく $10 \times 10^{-3}$ $\mathrm{mol} / l(\Delta)$ と $5 \times 10^{-3} \mathrm{~mol} / l(\bigcirc)$ とでは拡がり面積は非常に 異 なっている。

以上ニトロセルロース溶液の水面上の拡がりについての種々の 実験結果をのべた。もっとも問題となるのは希薄溶液の部分に持 ける重合度の差による搪がりの逆転である。逆転後の膜の状態は 高重合度のほらが穴の多い疎な膜であることが観察された。これ は薄膜を利用する実用上の大きな問題である。

この報告にあたり種々御討論下された颃茶の水大学立花教授括 よび同教室の方，表面張力の測定装置を教示された当研究所久保 田研究員に厚く御礼申し上げます。

温度が增加すると溶媒の蒸発速度が大きくな り, 粘度おさび表面張力が拡がりに影響している あいだに膜は固定化するから，交点はあらわれな い。図 10 に粘度の温度変化を示した。温度が上 ると粘度は相対的に低下するが，重合度の差によ る粘度の相対的な差は一定濃度で注温度が増加し ても変わらない。また温度の上年によって $\gamma_{B}$ も $\left(r_{\mathrm{A}}+r_{\mathrm{AB}}\right)$ も減少するので $S_{\mathrm{AB}}$ はそれ注ど変化 がないと考兄られる。

図 11 火は溶剂をかえた場合の濃度（\%) と拡 がりの関係を 3 種の未分別ニトロセルロースを用 いて示した。溶剂の蒸発速度が拡がりに影響して いるが，重合度すなわち粘度の方がさらに大きい 影響をもっていることがわかる。

図 12 には可塑剤の影響を示した。低温ほど㧪 がりは大きいが、そ搪がりが一定になるような 温度 (A) が存在し，その温度以下では拡がりは 温度に関係しない。またこの温度は滴下量に関係 がない。たと兊ば $5 \times 10^{-3} \mathrm{~mol} / l$ 濃度で○と口は 滴下量に差があるが $\mathrm{A}$ 点は変わらない。しかし可

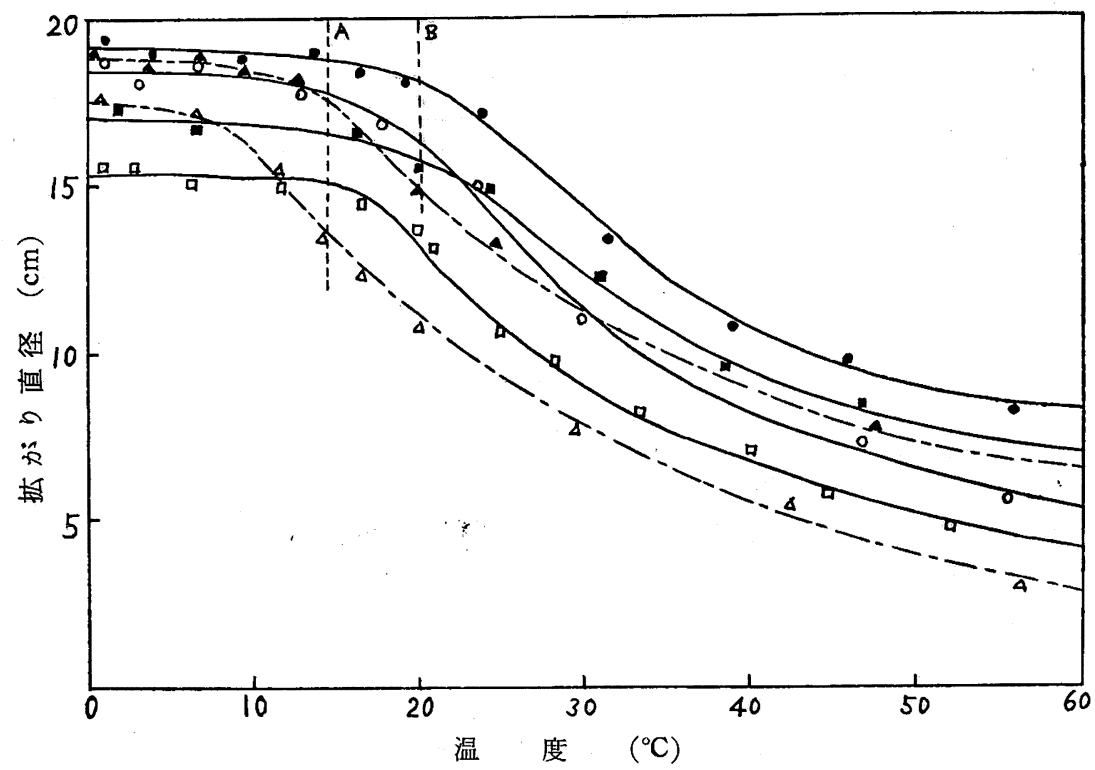

困 12 可塑剤 の 影響

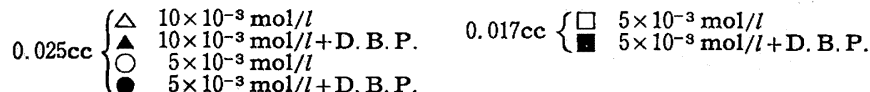
$5 \times 10^{-3} \mathrm{~mol} / l+$ D. B.P.

\title{
トリプチルホウ素触媒から得られたポリビニルアルコールのニ, 三の性質
}

（昭 和 35 年 1 月 11 日 受 理)

井手 文雄・高山雄二*

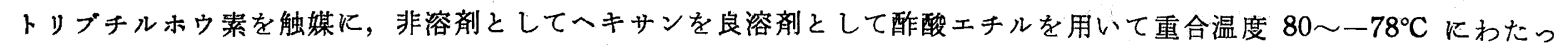
て酢酸ビニルの溶液重合を行ない，えられた拉のおのポリビニルアルコールを重合率，重合度，分岐，1，2-グリコール 結合量, 膨潤度, 溶解度, 結晶化度の立場から比較検討した。その結果, 両溶剤からえられたポリビニルアルコールの間

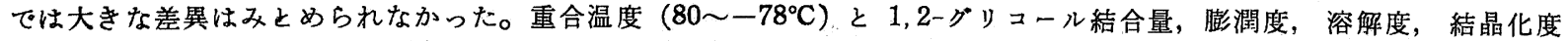
の関係ならびに熱処理温度と結晶化度, 膨潤度等と結晶化度の関係をむえた。

\section{1 緒言}

一般に溶液重合に特いて溶剂が非溶剤であると重合体ラジカル

$†$ 本報を「トリアルキルホウ素による酷酸ビニルの重合（第 3 報)」とする.

* 三菱レイヨン株式会社：東京都中央区京楿.
は屈曲した分子形態をとり，良溶剤では比較的のびた形をとって いる。そのために非溶剤からえられた重合体の重合度は良溶剤の それよりも大きいと考えられる。その上非溶剤では重合の進行と ともに重合体が沈降するので重合の場に括ける重合体の濃度は低 くなる。ポリ酢酸ビニルのように重合体の連鎖移動反応によって 分岐が生じる場合には，重合の場に拈ける重合体の濃度が低い非 
溶剤系からえられた重合体の方が分岐が少ないと想像される。以 上のような考えに基ついて非溶剤としてへキサン，良溶剤として 酢酸エチルを用い, 重合温度を 80 〜 $78^{\circ} \mathrm{C}$ の範囲にわたってか え, えられたポリビニルアルコールの重合率, 重合度, 分岐, 1 , 2-グリコール結合量, 膨潤度, 結晶化度について比較検討した。 さらにその過程に扎いて 1,2-グリコール結合量, 膨潤度, 溶解 度, 結晶化度等と重合温度の関係を追究するとともに熱処理温度 と結晶化度との関係も検討した。その結果を報告する。

\section{2 実 験 の 部}

\section{$2 \cdot 1$ 試薬}

トリブチルホウ素 : 臭化ブチルマグネ シウムと三フッ化ホウ素との反応によっ て合成。 $\mathrm{bp}=86 \sim 89.5^{\circ} \mathrm{C} / 8 \sim 9 \mathrm{mmHg}$ 。

酢酸ビニル：酸性亜硫酸ソーダ溶液で 洗ったのち, 水洗をくりかえし，常圧で 数回蒸留し, 使用直前減圧蒸留した。 $\mathrm{bp}=73^{\circ} \mathrm{C}$

酢酸エチル：少量の水を加兄て蒸留し たのち，常圧下で蒸留をくりかえした。 bp $77.0 \sim 77.2^{\circ} \mathrm{C}$ 。

ヘキサン: 硫酸で洗い水洗後カセイソ 一ダ溶液で洗い，次にアルカリ性過マン ガン酸カリ液で洗い, 水洗後金属ナトリ ウムで乾燥, 蒸留をくりかえした。

\section{$2 \cdot 2$ ケ ン 化}

ポリ酢酸ビニルのケン化は既報1) と同 様にカセイソーダ溶液で 1 次, 2 次ヶン 化した。

\section{$2 \cdot 3$ 重 合}

重合は既報 ${ }^{2)}$ と同様に行なった。すな わち窒素箱の中で重合試薬を重合管の中に入れたのち, 規定量の 酸素を導入して回転または静置重合した。

\section{$2 \cdot 4$ ポリビニルアルコール膜の熱処理}

熱処理は膨潤度用のものは，シリコーン油中で行ない，ペンゼ ンにひたして十分油を除いたのち，アセトンにひたし，真空デシ ケーター中で乾燥した。赤外線スペクトル用の膜はわくをつけた まま油の中で上と同様に熱処理を行ない，ベンゼンにひたしたの ち真空デシケーター中で埧燥した。

\section{$2 \cdot 5$ 膨潤度ならびに溶解度}

ポリビニルアルコールの膜を蒸留水の入っている大型の試験管 に入れ, $30^{\circ} \mathrm{C}$ の恒温槽の中に 24 時間放置後とり出し, 表面の水 を口紙でふきとり科量, 乾燥した。膨潤度ならびに溶解度は次の 式で表示した。すなわら

$$
\text { 膨潤度 }=\frac{\text { 膨潤皮膜の重量一膨潤後乾燥した皮膜の重量 }}{\text { 膨潤後乾燥した皮膜の重量 }} \times 100
$$

溶解度 $=\frac{\text { 膨潤前の乾燥皮膜の重量一膨潤後乾燥した皮膜の重量 }}{}$ $\times 100$

1) 井手，高山，工化 63，529 (1960).

2) 井手, 高山, 工化 63,533 (1960).

\section{3 実験結果ならびに考察}

\section{$3 \cdot 1$ 重合率，重合度ならびに分岐}

良溶浏として酷酸エチル，非溶剤としてへキサンを用い， $80^{\circ}$ ， $40^{\circ}, 0^{\circ},-78^{\circ} \mathrm{C}$ の各温度で重合を行なった。結果を表 1 K示す。

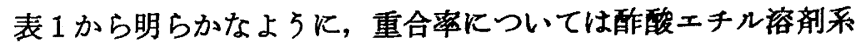
がへキサン系よりも全般的に大きいが，重合温度が低くなるにつ れて両者の差は縮まり， $-78^{\circ} \mathrm{C}$ においてはほとんど差がない。

重合度については $-78^{\circ} \mathrm{C}, 0^{\circ} \mathrm{C}, 40^{\circ} \mathrm{C}$ ではへキサン系の方が より大きい值を示しているが， $80^{\circ} \mathrm{C}$ とおいては酢酸エチル系の
表 1 重合率, 重合度ならびK $\bar{P}_{\mathrm{Ac}} / \bar{P}_{\mathrm{A}}$

\begin{tabular}{|c|c|c|c|c|c|c|c|c|c|}
\hline 实験番号 & $\begin{array}{l}\text { 重合温度 } \\
\left({ }^{\circ} \mathbf{C}\right)\end{array}$ & $\mathrm{kmol} / \mathrm{l}$ & 溶 郕 & 重合時間 & $\begin{array}{l}\text { 酸素/触媒 } \\
\text { (モル比) }\end{array}$ & $\begin{array}{l}\text { 重合率 } \\
\text { \%) }\end{array}$ & $\bar{P}_{\mathbf{A c}}$ & $\bar{P}_{\mathbf{A}}$ & $\bar{P}_{\mathbf{A}} / \bar{P}_{\mathbf{A}}$ \\
\hline No. $52-2$ & 80 & 0.005 & 酶酸エチル & 19分 & - & 45.3 & 860 & 860 & 1.00 \\
\hline-1 & $"$ & " & " & 26 & - & 58.5 & 1293 & 1105 & 1.17 \\
\hline-3 & " & " & " & 50 & - & 71.2 & 1232 & 1070 & 1.15 \\
\hline-7 & " & " & ヘキサン & 36 & - & 51.0 & 822 & 882 & $(1.00)$ \\
\hline-8 & " & " & " & 38 & - & 51.3 & 875 & 870 & 1.00 \\
\hline-9 & "I & " & " & 52 & - & 54.6 & 807 & 800 & 1.00 \\
\hline No. $51-7$ & 45 & 0.03 & 酢酸エチル & 45分 & 0.04 & 44 & 930 & 1055 & $(1.00)$ \\
\hline-5 & " & " & " & $\begin{array}{c}1 \text { 時䦭15分 } \\
(1-15)\end{array}$ & " & 63.0 & 1150 & 1100 & 1.05 \\
\hline-6 & " & " & " & $1-45$ & " & 76.3 & 1247 & 1200 & 1.04 \\
\hline-2 & " & " & ヘキサン & $2-00$ & " & 67.5 & 1435 & 1250 & 1.14 \\
\hline-1 & " & " & " & $2-45$ & " & 71.0 & 1550 & 1210 & 1.27 \\
\hline-3 & " & " & " & $3-40$ & " & 77.5 & 1343 & 1190 & 1.12 \\
\hline-4 & $"$ & " & " & $4-30$ & " & 82.5 & 1356 & 1120 & 1.21 \\
\hline No. $52-4$ & 0 & 0.05 & 酶酸エチル & $22-15$ & 0.03 & 63.5 & 2205 & 1932 & 1.14 \\
\hline-5 & " & " & " & $43-00$ & 0.02 & 86.0 & 1532 & 1594 & $(1.00)$ \\
\hline-6 & " & " & " & $93-30$ & 0.03 & - & 2187 & 1680 & 1.30 \\
\hline-11 & " & $"$ & ヘキサン & $23-00$ & $"$ & 52.3 & 1965 & 1492 & 1.31 \\
\hline-12 & " & " & " & $43-00$ & " & 64.5 & 2187 & 1745 & 1.25 \\
\hline-10 & " & $"$ & " & $92-45$ & $"$ & 75.3 & 2340 & 1684 & 1.39 \\
\hline No. 53-6 & -78 & 0.065 & 酢酸エチル & $43-30$ & 0.03 & 16.5 & 1615 & 1624 & $(1.00)$ \\
\hline-5 & " & " & " & $95-30$ & " & 25.0 & 1850 & 1800 & 1.03 \\
\hline-5 & " & " & " & $144-00$ & " & 28.0 & 1370 & 1380 & $(1.00)$ \\
\hline-1 & " & " & ヘキサン & $43-30$ & $"$ & 19.5 & 2167 & 2077 & 1.04 \\
\hline-2 & " & " & " & $95-30$ & " & 26.0 & 2050 & 2000 & 1.03 \\
\hline-3 & " & " & " & $144-00$ & $"$ & 25.0 & 2200 & 2090 & 1.05 \\
\hline
\end{tabular}

方が大きい。前にのべたように，一般に重合体ラジカルは非溶剤 中では比較的屈曲した分子形態をとり，そのため重合体ラジカル 同志に上る停止反応が起りがたいので，比較的のびた形をとって いる良溶剤系でえられた重合体よりも非溶剤系のそれは大きい重 合度をもつと考兄られる。表 1 は一応それを稁付ける結果を示し ているわけであるが， $80^{\circ} \mathrm{C}$ に怙いて逆の結果がえられている。 これは重合温度が高くなるにつれて屈曲した重合体ラジカルの反 応性が増大するためであろ5（すちろん酥酸ビニルの重合体の重 合度は溶剤の連鎖移動反応の大きな影響をろけるので溶郕の連鎖 移動定数の溶度変化を考虑しなければならないが，一応その効果 を除いて考える)。

表 1 の右側に酶酸基からの分岐の度合を示するのとして $\overline{\boldsymbol{P}}_{\mathrm{ACl}}$ $\bar{P}_{\mathrm{A}}$ の值を示した。非溶剤系中での重合においては重合の進行と ともに重合体が沈降するので重合の場における重合体の閝度は一 般に低いと考えてよい。分岐は重合体の連鎖移動反応によって生 じるとすると、へキサン系からえられたポり酢酸ビニルの分岐は より少ないと考えられるが， $\bar{P}_{\mathbf{A c}} / \bar{P}_{\mathbf{A}}$ の值は両者の間ではとんど 差がなかった。これは多分へキサン溶剤中で分離沈降した重合体 が相当単量体を含んでいるので，さらにこの沈降した重合体の中 で重合が幾分進行するためであろう。 


\section{$3 \cdot 2$ 1,2-グリコール結合}

Flory の粘度法3)によってポリピニルアルコールの 1,2-グリコ ール結合量を求めた。その結果を図 1 亿示す。1,2-グリコール結

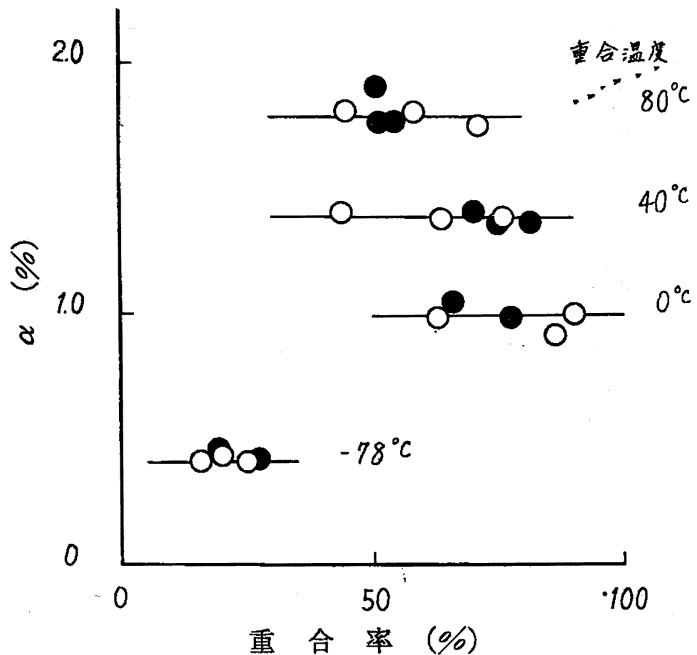

図 1 1,2-グリコール結合と重合率の関係

○酶酸エチル・・キサノ

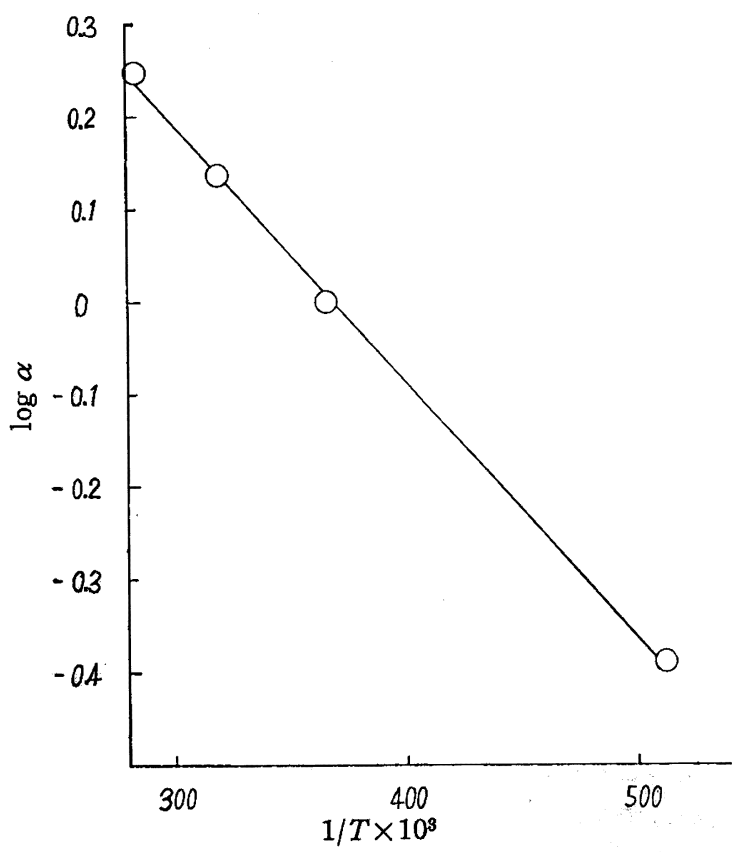

図 $2 \log \alpha$ と $1 / T$ の関係

$E=1.35 \mathrm{kcal} / \mathrm{mol}$

合量 $(\alpha)$ は両溶剂の間で差がみとめられなかった。さらに $\alpha$ は 重合率に無関係に括の括のの重合温度で一定の值を示している。

図 2 は $\log \alpha$ と絶対温度の逆数の関係を示したものである。直 線の勾配から活性化エネルギーを求めた。

$$
E=1.35 \mathrm{kcal} / \mathrm{mol}
$$

この值は著者らが前に ${ }^{1)}$ 重合温度 $80 \sim 20^{\circ} \mathrm{C}$ の範囲で求めた值 と大体同じである。

\section{$3 \cdot 3$ 菿潤度, 結晶化度}

両溶骫からえられたポリビニルアルコールのを膜つくり，重合 温度 $80^{\circ} \mathrm{C}, 40^{\circ} \mathrm{C}, 0^{\circ} \mathrm{C}$, の各ポリビニルアルコール膜については 熟処理温度と膨潤度, 溶解度の関係を求め, さらに重合温度の膨

3) P. J. Flory, F. S. Leutner, J. Polymer Sci. 3, 880 (1948); ibid. 5, 267 (1950).
潤度ならびに溶解度に対する影響を検討した。

$50^{\circ} \mathrm{C}, 90^{\circ} \mathrm{C}, 120^{\circ} \mathrm{C}, 160^{\circ} \mathrm{C}$ の各温度で熱処理したポリビニルア ルコール膜の膨潤度ならびに溶解度を求めた。困 3 , 図 4 , 困 5 は重合温度 $80^{\circ} \mathrm{C}, 40^{\circ} \mathrm{C}, 0^{\circ} \mathrm{C}$ のポリビニルアルコール膜の膨潤 度ならびに溶解度と熱処理温度との関係を示したものである。こ れらの図より明らかであるように，両溶剤からえられたポリビニ ルアルコール膜の膨潤度と溶解度には差がみとめられない。膨潤

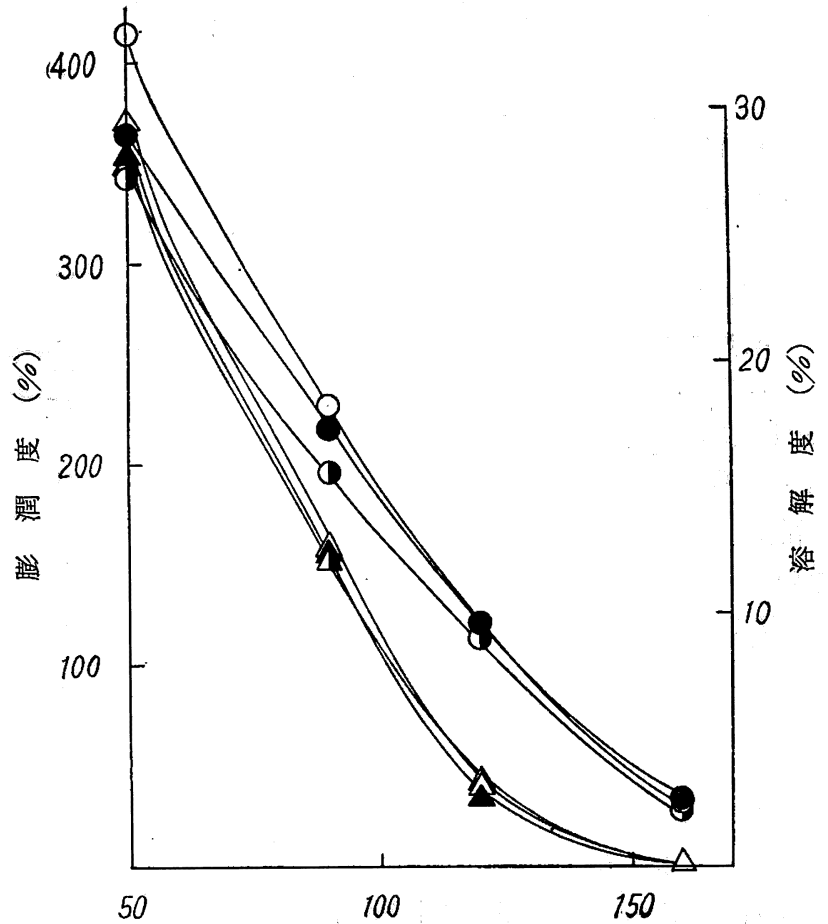

熱処理温度

図 3 重合温度 $0^{\circ} \mathrm{C}$ の膨潤度と熱処理温度の関係 膨潤度 $\left\{\begin{array}{ll}\bigcirc & \text { No. } 52-1 \\ \mathbf{0} & \text { No. } 52-3 \\ \mathbf{O} & \text { No. } 52-9\end{array} \quad\right.$ 溶解度 $\begin{cases}\Delta & \text { No. } 52-1 \\ \mathbf{\Delta} & \text { No. } 52-3 \\ \mathbf{\Delta} & \text { No.9 }\end{cases}$

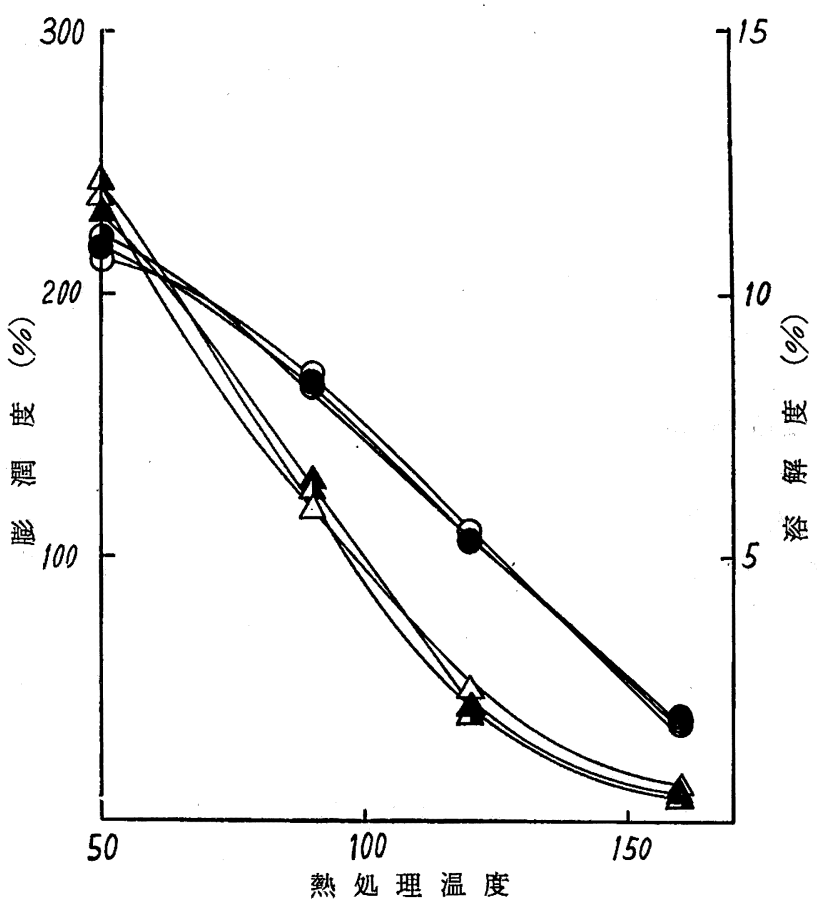

図 4 重合温度 $40^{\circ} \mathrm{C}$ の膨潤度と熱処理温度の関係 膨潤度 $\left\{\begin{array}{ll}0 & \text { No. } 51-3 \\ \text { No. } 51-4 \\ \text { No. } 51-6\end{array} \quad\right.$ 溶解度 $\begin{cases}\Delta & \text { No. } 51-3 \\ \Delta & \text { No. } 51-4 \\ \Delta & \text { No. } 51-6\end{cases}$ 


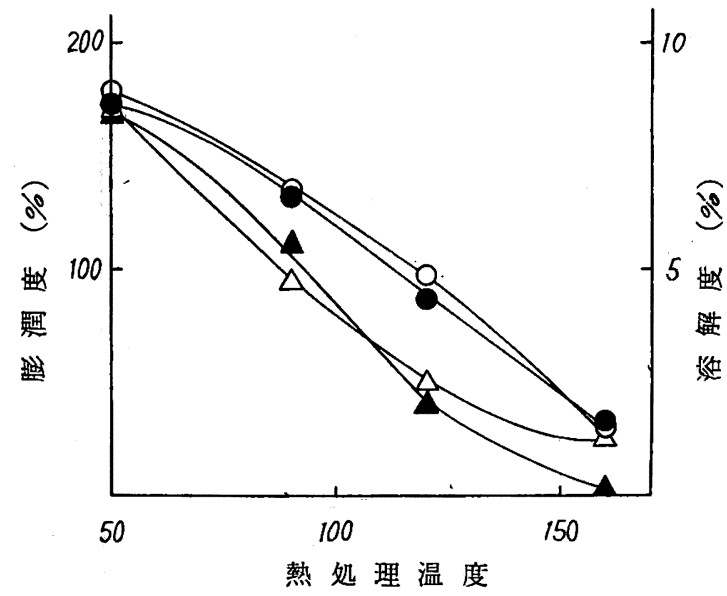

因 5 重合温度 $80^{\circ} \mathrm{C}$ の膨潤度と熱処理温度の関係

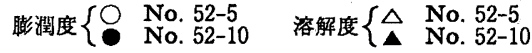

度, 溶解度ともに熱処理温度の増大とともに減少し，熱処理によ って結晶化の進行していることを裏付けているが，熱処理温度が $160^{\circ} \mathrm{C}$ 以上になると重合温度に無関係に同一の值を示す。

膨潤度に影響をあたえる因子として重合温度があげられる。こ のことに関しては有機過酸化物触媒からえられたポリビニルアル コールについて浮田ら齐の報告があり, 重合温度への依存性が指 摘された。藤井ららはトリエチルホウ素からのポリビニルアルコ ールについて同様の実験を行った。著者らも松本らと同様の立場 から実験を行なっていた。その結果を図 6 に示す。この実験に用 いたポリビニルアルコール膜は溶剤ならびに重合温度の影響をよ り明白に知るために熱処理を行なわなかった。図6に示すよ5に 重合温度 $-78 \sim 80^{\circ} \mathrm{C}$ にわたって膨潤度, 溶解度ともに両溶剤系 で差がない。

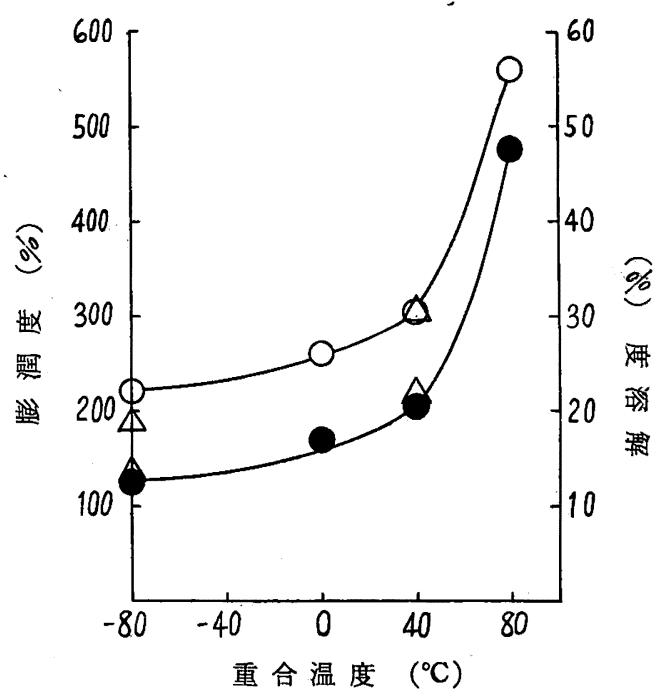

因 6 澎潤度, 溶解度と重合温度の関係

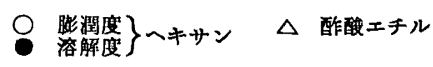

重合温度に関しては明らに依存性があり，重合温度の低下とと もに膨潤度，溶解度は減少するがその影響が重合温度 $40^{\circ} \mathrm{C}$ 以上 では非常に大きいが，0C 以下では小さい。

次に今まで測定した膨潤度と溶解度の関係を図 7 K示した。こ れらのポリビニルアルコール膜は重合度 900 2300, 重合温度

4) 浮田, 内藤, 小南, 工化 58, 128 (1955).

5) 藤井, 汇口, 浮田, 松本, 高分子化学 16，519 (1959),

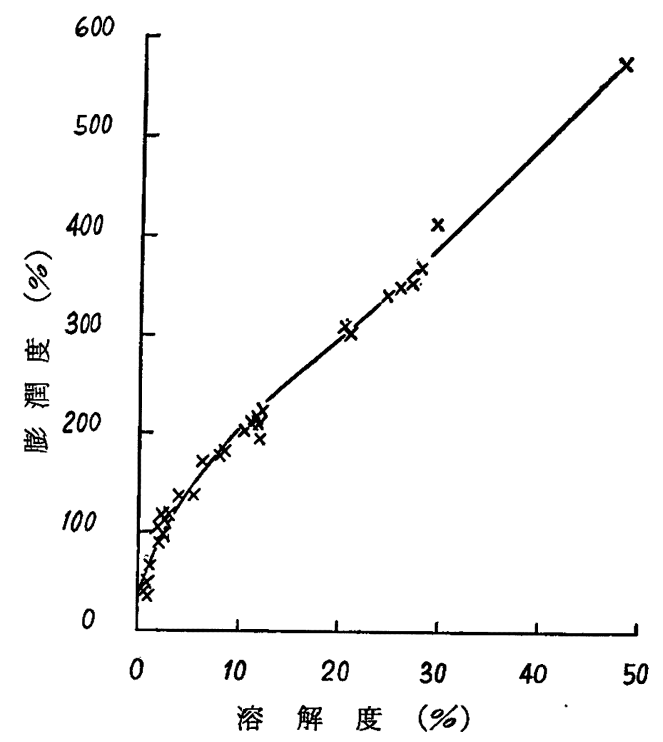

圀 7 膨潤度と溶解度の関係

-78 $\sim 0^{\circ} \mathrm{C}$, 熱処理温度は無処理と $40 \sim 160^{\circ} \mathrm{C}$ と非常に種々の試 料を含んでいるにもかかわらず大体 1 本の曲線であらわされる。 すなわち重合温度, 重合度, 熱処理温度に無関係であり, 少なく ともこの実験条件下では膨潤度は溶解度に一義的に関係つけられ る。もちろん成膜の製造条件が極めて大きな影響をあたえること は桜田 $5^{6)}$ ，井本ら7)によって報告されているが，この実験では 全試料とも室温で自然乾燥により成膜したものである。

\section{4 結 晶 化 度※1}

赤外吸収スペクトルによる結晶化度を示すバンドすなわち結晶 化バンドとして $8.7 \mu$ の吸収をとりあげ，熱処理温度ならびに 重合温度との関係を検討した。図 8 は重合温度 $0^{\circ} \mathrm{C}$ でえられた二 試料のポリビニルアルコールについて $D_{8.7} / D_{9.1}$ 'と熱処理温度と の関係を示したものである。二試料とも同じ傾向をすつ曲線がえ られ，熱処理温度に比例して $D_{8.7} / D_{9.1}$ は増大している。四 9 は 結晶化度と重合温度の関係を示す。図の示すと括り両溶剂の間で は結晶化度に関しては差がない。結晶化度は重合温度の增大とと

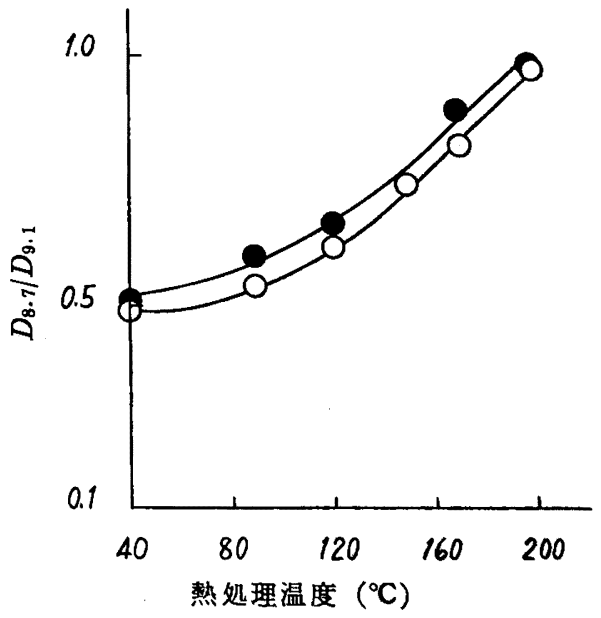

因 8 結晶化度と熱処理温度の関保 $\bigcirc$ No.51-2 $\rightarrow$ No.51-5

6) 桜田, 温品, 曾根, 高分子化学 12、510 (1955)、

7) 井本, 浮田, 高分子化学 16,340 (1959).

※1 結晶化度という言莱で表現するのは正しくない。正碓には

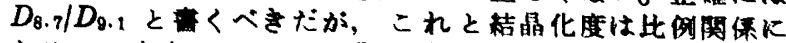
あるので本文においては $D_{8.7} / D_{9.1}$ を感味しているるのと する。 


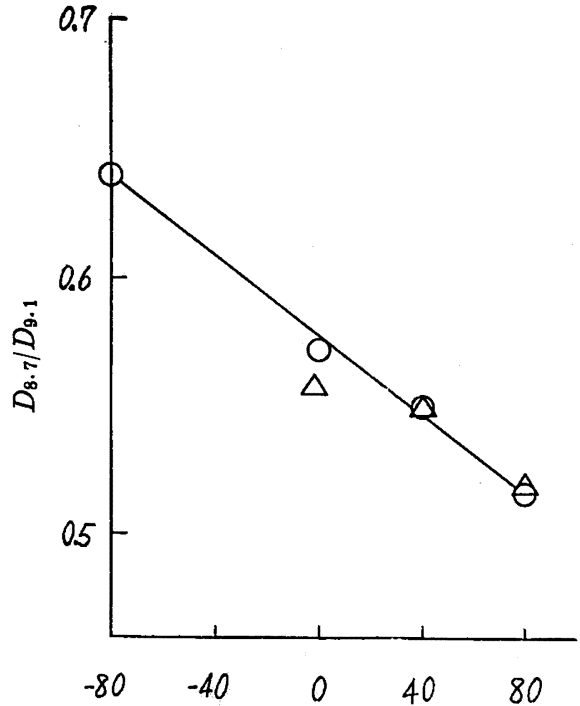

重合温度 $\left({ }^{\circ} \mathrm{C}\right)$

図 $9 D_{8.7} / D_{9.1}$ と重合温度の関係

○ヘキサン $\Delta$ 酢酸エキル

もに減少し，反比例の関係にある。このことは以前から指摘され ていたように重合温度の低下とともに，1,2-グリコール結合量が 减少し，分岐が少なくなるために結晶化度が大きくなるのであろ う（もちろん低温になるにつれて $\mathrm{OH}$ の立体的配置の規則性が結 晶性に及ぼす影響も考えにいれなければならない)。

図 10 は結晶化度と膨潤度ならびに溶解度の関係をあらわした ものである。この図は温品8)らによって測定されたX線小角散乱 法による結晶化度と膨潤度の関係を示した図と類似している。し

8) 桜田編,「ポリビニルアルコール」p. 313.

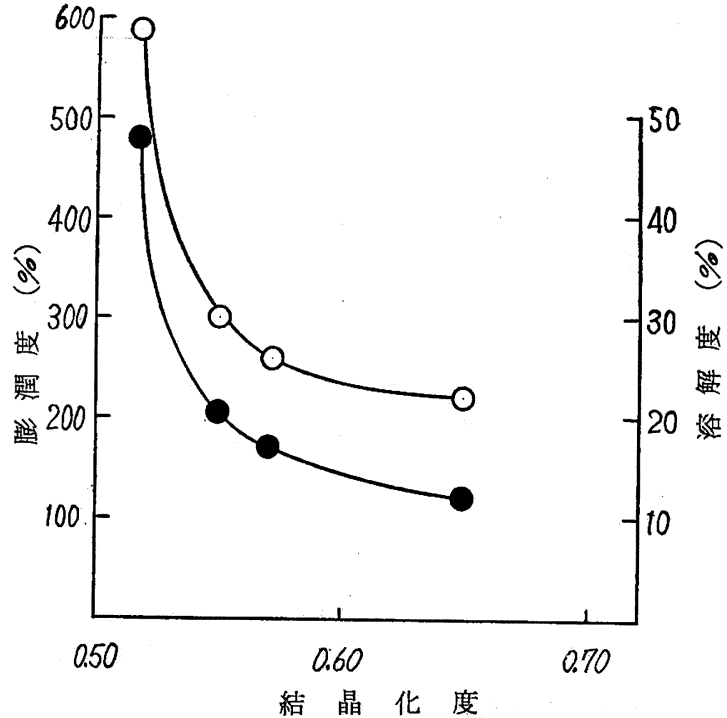

図 10 膨潤度, 溶解度と結晶化度の関係

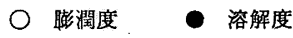

かし温品らのものはX線による結晶化度であり，かつ結晶化度を かえるのに熱処理温度をかえているのに対して，著者らは赤外吸 収スペクトルから求められた結晶化度であり，結晶化度をかえる のに重合温度によるものであるといら差異があるので，直ちに同 一に論ずることはできないが，図の示すように結晶化度のわずか の違いが膨潤度に大きな効果をあたえる部分と，そうでない部分 から成り立っている。前者では結晶化度以外の因子すなわち非結 晶部分の平㘬の鎖長が影響していると考えられる。

(本論文の一部は昭和 34 年度化学関係学協会連合秋季研究発 表大会にて講演)

\title{
クリニャール試薬によるメチルメタクリレートの重合 に及ばす溶媒および温度の影響†
}

(昭 和 35 年 3 月 17 日受 理)

渡 辺治 昭*

\begin{abstract}
メチルメタクリレートをグリニャール試薬によって重合する際，溶媒および温度がいかなる影響を与えるかを追求し た。まず重合温度は低温の方が室温より高分子物を高収率で得られ，溶媒としてはエーテルより，トルエン，クロロホル ム，または何も使用しない方が重合率扰よび分子量ともに大きい。次に開始剤としてはグリニャール試薬のエーテル溶液 を使用するより，トルェン，ヘプタン溶液を使用する方が効率がよかった。低温で出来た重合体はアセトン不溶，ペンゼ ンに熱時可溶，冷えるとゲル化する特異な溶解性を示し，赤外線スペクトルも $760 \mathrm{~cm}^{-1}$ K新しい四収を生じた。
\end{abstract}

\section{1 緒 言}

最近，有機金属化合物を触媒とする鎖状高分子の重合が活発に 研究されている。メチルメタクリレート (以下 M. M. A. と記す) を有機金属化合物によって重合する方法として，Fox ら1) は有機 リチウム化合物によって三つの型, すなわち, type I, type II,

† 本研究を「クリリニール試薬によるメチルメタクリレート の重合（第1報）」とする.

* 日本電信電話公社電気通信研究所：東京都武蔵野市吉祥寺。 type III の重合物をつくり，それぞれ異なった立体特異性をもち 結晶可能であることを示して拈り，Korotkov2) は クーブチルリチ ウムによって遊離ラジカル型の重合体と溶解性の異なるポリ $\mathrm{M}$.

M. A. ができることを示している。更に Rohm \& Hass Company

1) T. G. Fox, B. G. Garrett, W. E. Goode, S. Gratch, J. F. Kincaid, A. Spell, J. D. Stroupe, J. Am. Chem. Soc. 80, 2341 (1958).

2) N. G. Gaylord, H. F. Mark, Linear and Stereoregular Addition Polymers p. 254. (1959) Interșcience Publishẹers Ltd, 